\title{
Kina: selvsikker \\ og ambitiøs stormagt
}

Af Camilla T. N. Sørensen

Anført af præsident Xi Jinping træder

Kina frem som en selvsikker og ambitiøs stormagt. Det er slut med kinesisk insisteren på, at Kina er et udviklingsland med fokus på egen økonomisk udvikling. Beijing udviser anderledes vilje og mod til at tage stormagtsansvar og en international lederrolle på særlige udvalgte områder, men kræver til gengæld stormagtsindflydelse og respekt.

I den konkret førte kinesiske udenrigsog sikkerhedspolitik er der en tydelig bevægelse væk fra Deng Xiaopings 'hold lav profil'-doktrin. Kinesiske ledere, diplomater og repræsentanter for store statsejede virksomheder rejser verden rundt og indgår strategiske partnerskaber, præsenterer kinesiske bud på håndteringen af internationale konflikter og udfordringer, byder ind på store projekter og opkøber virksomheder $i$ et hidtil uset omfang.

Xi Jinping har aflagt besøg i ikke mindre end 57 lande i de 5-6 år, han har siddet ved magten. Meget af dette finder sted i regi af Xi Jinpings store prestigeprojekt 'Den Nye Silkevej', hvor Kina sætter sig selv i spidsen for bestræbelser på at skabe international økonomisk vækst og udvikling via finansiering og etablering af store infrastrukturprojekter.

Det skal ende ud i nye internationale handels-, transport- og kommunikationsveje, der udspringer i Kina og forbinder landet - især de underudviklede provinser i Midt- og Vestkina - med vigtige markeder og partnere i særligt Europa, men også Afrika og Mellemøsten.

Beijing satser også i stigende grad på at udbrede egne værdier og ideer. Udvalgte kinesiske statsejede medier opretter afdelinger uden for landets grænser med fokus på at nå og påvirke et udenlandsk publikum. Som $\mathrm{Xi}$ Jinping understregede i sin tale til den 19. Partikongres i efteråret 2017, har Kina andet og mere end blot økonomisk vækst at tilbyde andre lande - der er bl.a. kinesiske erfaringer og tanker om indretning og reformer af $\varnothing$ konomiske og politiske systemer, der, samlet under overskriften 'Xi 
Jinpings tanke om socialisme med kinesiske særtræk i den nye æra', fremhæves som et alternativ for lande, især udviklingslande, som søger økonomisk vækst og samtidig fastholdelse af national uafhængighed.

Det nye hold, som Xi Jinping med den 19. Partikongres i efteråret 2017 efterfulgt af Folkekongressen

\section{Mens det i høj grad fortsat er den indenrigs- politiske udvikling og dagsorden, der prioriteres og sætter rammerne for uden- rigs- og sikkerhedspolitikken, så er der tegn på, at Xi Jinping har stærkere stormagts- visioner for Kina og i højere grad end sine forgængere er villig til at tage økonomiske og militære instrumenter $i$ anvendelse.}

kinesisk interessesfære og kinesiske kerneinteresser.

Denne artikel udpeger de vigtigste drivkræfter bag udviklingen af Kina som en selvsikker og ambitiøs stormagt. Hovedargumentet er, at det er samspillet mellem ændrede systemiske - dvs. udviklinger i magtbalancen mellem USA og Kina - og indenrigspolitiske udfordringer og dynamikker, som det er vigtigt at få fat $\mathrm{i}$.

Der skitseres løbende en række perspektiver for den videre udvikling i kinesisk udenrigs- og sikkerhedspolitik samt forventelige implikationer i og uden for Asien. i foråret 2018 - har sat i spidsen for Kina, understøtter ligeledes, at udenrigs- og sikkerhedspolitikken har fået større fokus. Bl.a. er den tidligere udenrigsminister, og før det ambassadør i USA, Yang Jiechi nu at finde i Politbureauet, som er øverste - top25 - i kommunistpartiet og dermed i Kina. Der foregår også en generel styrkelse af kinesiske diplomater og ambassader.

Mens det i høj grad fortsat er den indenrigspolitiske udvikling og dagsorden, der prioriteres og sætter rammerne for udenrigs- og sikkerhedspolitikken, så er der tegn på, at Xi Jinping har stærkere stormagtsvisioner for Kina og i højere grad end sine forgængere er villig til at tage økonomiske og militære instrumenter $i$ anvendelse for at demonstrere og sikre, hvad Beijing ser som legitim
Ændret magtbalance og rivalisering Den amerikansk-ledede verdensorden har været en nødvendig forudsætning for Kinas hastige udvikling fra et internationalt isoleret udviklingsland sidst i 1970'erne til i dag - kun 40 år efter - at stå som en økonomisk og militær stormagt.

Den kolde krigs afslutning muliggjorde, at kinesiske ledere kunne flytte fokus i udenrigs- og sikkerhedspolitikken fra spørgsmål om Kinas position og interesser i den overordnede rivalisering mellem USA og Sovjetunionen til sikringen af de bedste betingelser for Kinas $ø$ konomiske reformprogram. Som led heri blev Kinas økonomi koblet på den økonomiske globalisering, og Beijing øgede landets engagement $\mathrm{i}$ internationale multilaterale samarbejder, særligt på det økonomiske område. 
USA blev hurtigt en central handelspartner og kilde til udenlandske investeringer, og for Beijing blev relationen til USA den vigtigste bilaterale relation overhovedet, hvor sikring af stabilitet via samarbejde og dialog stod øverst. Dette er baggrunden for Deng Xiaopings 'hold lav profil'-doktrin, der siden starten af 1990 'erne har stået som den overordnede rettesnor for kinesisk udenrigs- og sikkerhedspolitik.

Doktrinen foreskriver, at Beijing skal prioritere opbygningen og fastholdelsen af stabile relationer til regionale lande og vigtige handelspartnere og derudover holde lav profil internationalt og undgå at blive blandet ind $i$ andre landes konflikter og undgå at bruge for mange ressourcer på udviklinger og begivenheder i det internationale system, som ikke berører Kinas kerneinteresser.

En anden af doktrinens formaninger er, at kinesiske ledere skal arbejde hårdt for at forsikre om Kinas fredelige hensigter for herved at forebygge eller modvirke udviklingen af en stærk 'Kina-trussel'-opfattelse særligt blandt de regionale lande.

'Hold lav profil'-doktrinen har fungeret godt, men nu har den imidlertid nået sin grænse og holder ikke længere. Kina er blevet for stor og møder stigende forventninger og krav; fra internationalt hold er det forventninger om, at Kina tager større ansvar for håndteringen af internationale konflikter og udfordringer, mens de indenrigspolitiske forventninger snarere går på, at Beijing mere proaktivt forfølger kinesiske kerne- interesser og beskytter kinesiske borgere og investeringer rundt omkring i verden.

Helt overordnet har Kina fået for store interesser i udviklingen i det internationale system og $i$ andre lande til at fortsætte med at holde lav profil og indordne sig under USA. Beijing vil heller ikke længere acceptere, at USA har særlige privilegier i det internationale system. Her bliver særligt USA's dominerende rolle og mange militære aktiviteter og massive militære tilstedeværelse i Kinas nærområde i stigende grad fremhævet som tegn på manglende amerikansk respekt.

Set fra Beijing er Østasien Kinas legitime interessesfære, og det er kineserne mere højlydt begyndt at kræve, at USA respekterer. Det er derfor en tiltagende strategisk rivalisering mellem USA og Kina, som især udspiller sig i Østasien, men også i stigende grad har implikationer uden for regionen. Det er ikke overraskende. Som såvel de forskellige varianter af magttransitionsteorier som den historiske lære peger på, er strategisk rivalisering forventelig, måske endda uundgåelig, når en opstigende magt begynder at kunne udfordre en eksisterende stormagt, så denne ikke længere enerådigt kan forme verdensordenen i overensstemmelse med egne interesser.

\section{Donald Trump og Kina}

Med Donald Trump i Det Hvide Hus er udviklingen af Kina som en selvsikker og ambitiøs stormagt blevet yderligere fremskyndet. Den stigen- 
de usikkerhed omkring amerikanske forpligtelser og løfter har kun givet Kina et større handlerum og åbnet nye muligheder.

På den anden side har Trump-administrationen klart identificeret Kina som en strategisk konkurrent og nærer ingen illusioner om, at USA ved at engagere og samarbejde med Kina kan skubbe på for demokratisering i landet. Dette har ellers været et bærende element $\mathrm{i}$ amerikansk Kina-politik nærmest siden normaliseringen af relationerne mellem de to lande i 1970'erne. Nu synes der snarere at være en generel konsensus i Washington om, at den tidligere amerikanske analyse af, hvordan et atom- og missilprogram har medvirket til, at Trump-administrationen har holdt lavere profil på et af de øvrige store brændpunkter, hvor USA står over for Kina, nemlig Det Sydkinesiske Hav.

De amerikanske gennemsejlinger - de såkaldte 'Freedom of Navigation Operations' (FNOPs) - finder imidlertid fortsat sted. Det har ikke fået Kina til at indstille udbygningen af kunstige øer og militære installationer i området, og der er derfor et voksende pres i Washington for et stærkere modsvar, fx at USA etablerer en permanent militær tilstedeværelse ikke kun i Det Sydkinesiske, men også i Det Østkinesiske Hav.

Trump-administrationen har endnu ikke præsenteret et bud på en samlet Asien-strategi. På sin rundrejse i regionen i efteråret 2017 præsenterede Trump ideen om USA som lederen af 'A Free and Open

opstigende Kina skal håndteres, har været forfejlet og har skadet amerikanske - sikkerhedspolitiske og økonomiske - interesser.

Der skal derfor anderledes hårde metoder i brug. Det har så resulteret i amerikanske handelssanktioner, som især er rettet mod Kina og ifølge præsident Trump specifikt mod 'kinesisk tyveri af amerikanske teknologier', samt i opprioriteringen af amerikanske politiske, sikkerhedspolitiske og militære relationer med allierede og partnere i Asien inklusive Taiwan. Fokus på krisen omkring Nordkoreas
Indo-Pacific Order'. Det peger mod, at Trump-administrationen søger at 'strække' regionen ud og dermed gøre den mindre domineret af Kina samt at bringe især Indien, men også Australien og Japan, mere i spil i forhold til at balancere og inddæmme Kina.

Alt peger derfor på, at den strategiske rivalisering mellem USA og Kina vil tage yderligere til $\mathrm{i}$ årene frem. Det stiller de mindre regionale lande i svære situationer - langt de fleste har Kina som deres vigtigste økonomiske partner, mens USA fortsat er 
deres sikkerhedspolitiske garant. Nogle lande som fx Cambodia og Laos har valgt side til fordel for Kina, mens andre som $\mathrm{fx}$ Filippinerne og Singapore fortsat søger at spille på begge heste.

Også uden for Østasien viser implikationerne sig, og generelt reageres der i stigende grad på den mere selvhævdende kinesiske udenrigs- og sikkerhedspolitik og den gradvise udvidede kinesiske interesse- og indflydelsessfære. I Europa viser dette sig særligt i den intensiverede debat om håndteringen af kinesiske investeringer og opkøb af europæiske virksomheder og logistiske knudepunkter som $\mathrm{fx}$ den strategisk vigtige havn Piræus i Grækenland, som det statsejede kinesiske rederi COSCO nu ejer 67 pct. af.

Den såkaldte ' $16+1$ dialogmekanisme', som Kina har indgået med de central- og østeuropæiske lande, har yderligere styrket bekymringerne for en kinesisk del og hersk-politik over for EU. På den anden side er der ingen europæiske statsledere, som vil risikere at lægge sig ud med Beijing. Dertil er de økonomiske interesser for store, mens tiltroen til solidaritet og opbakning fra EU er for lille.

Som den strategiske rivalisering mellem USA og Kina tager yderligere til i årene frem, vil nære amerikanske allierede som Danmark blive sat under $\varnothing$ get amerikansk pres med forventning om klar opbakning og måske endda egentlig militære bidrag, hvilket også kan ske
Den indenrigspolitiske scene er den vigtigste for kinesiske ledere, da de er overbeviste om, at det er her, kommunistpartiets fremtid afgøres. Det primære hensyn i kinesisk politik er derfor altid at sikre partiets indenrigspolitiske legitimitet og magtmonopol.

i NATO-regi. Hvis Danmark vanen tro leverer, når Washington spørger, vil det skade Danmarks 'Omfattende Strategiske Partnerskab' med Kina potentielt med store $\varnothing$ konomiske og kommercielle omkostninger til følge. Det er derfor af afgørende vigtighed at gennemtænke, hvordan danske og bredere europæiske - interesser bedst varetages i en sådan situation.

\section{Nye indenrigspolitiske udfordringer} Den indenrigspolitiske scene er den vigtigste for kinesiske ledere, da de er overbeviste om, at det er her, kommunistpartiets fremtid afgøres. Det primære hensyn i kinesisk politik er derfor altid at sikre partiets indenrigspolitiske legitimitet og magtmonopol. Det er i sidste ende også dette hensyn, som kinesisk udenrigs- og sikkerhedspolitik styres af.

Øverst på dagsordenen er fastholdelse af stabilitet, økonomisk vækst og fremgang for alle kinesere samt status og respekt for Kina som stormagt i det internationale system. Det er disse søjler, som partiets indenrigspolitiske legitimitet hviler på. I takt med reformprocessen og åbningen af Kina er udviklingerne i det kinesiske samfund imidlertid blevet vanskeligere at håndtere og kontrollere, og relationen mellem kommunistpartiet og det kinesiske samfund er under pres i disse år. 


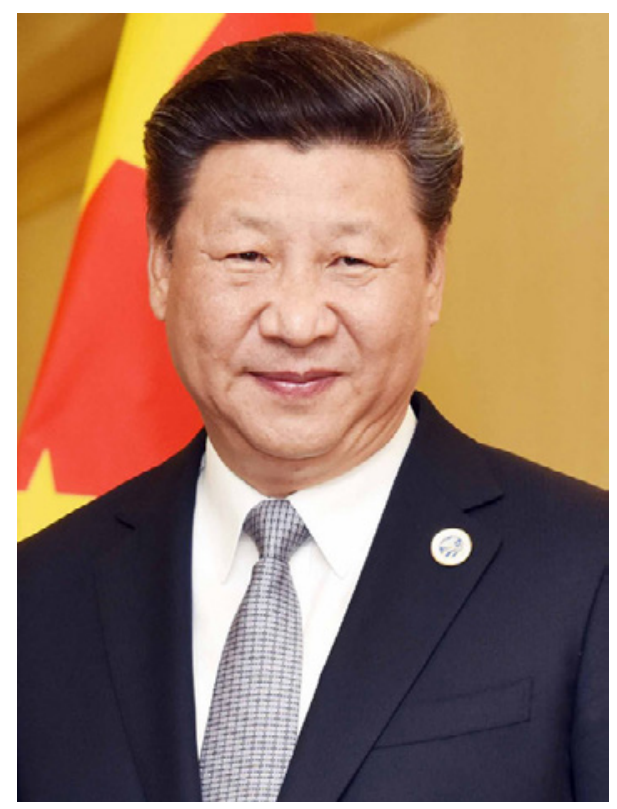

FOTO: Narendra Modi via Wikimedia Commons

Kinas præsident Xi Jinping, 2016

Anført af Xi Jinping har kommunistpartiet derfor indledt en offensiv kampagne for at genvinde befolkningens opbakning til og tro på partiet. Dette udmønter sig især i kampagnen for realisering af 'den kinesiske drøm', hvor et centralt element er den såkaldte genrejsning af det kinesiske folk og af Kina som Riget i Midten, der endelig har gjort op med 'de 100 års ydmygelser', hvilket er kinesernes betegnelse for perioden fra Opiumskrigen (18391842), hvor Kina blev besat og fordelt mellem stormagterne, til kommunisternes sejr i borgerkrigen og etableringen af Folkerepublikken Kina i 1949.

Kampagnen, i samspil med den ændrede magtbalance mellem USA og Kina, har yderligere styrket og le- gitimeret nationalistiske ambitioner og forventninger i store dele af den kinesiske befolkning. Nationalisme i Kina er komplekst med adskillige typer nationalisme, som kan føres tilbage til, hvordan nationalisme i Kina både er drevet af opfattelser af historisk ydmygelse og af historisk stolthed samt af stolthed over de seneste tre-fire årtiers kinesiske bedrifter.

Det vigtigste i denne sammenhæng er, at nationalisme har åbnet et legitimt rum for aktivisme og mobilisering i det kinesiske samfund, og med den større udbredelse af medier, mobiltelefoni og internet er sådanne nationalistiske grupper og strømninger blevet sværere at kontrollere.

Det paradoksale er, at det også er svært for kinesiske ledere at forbyde eller slå ned på nationalistiske demonstrationer, da de selv har opmuntret hertil og dermed gjort det legitimt og ligefrem patriotisk at ytre sig. Nationalismen har dermed udviklet sig til et tveægget sværd for kinesiske ledere. På den ene side kan de bruge nationalismen til at mobilisere den kinesiske befolkning med det formål at lægge pres på andre internationale forhandlingspartnere og til at fjerne opmærksomheden fra egne fejl og svagheder. På den anden side udvikles imidlertid kun endnu højere nationalistiske ambitioner og forventninger i den kinesiske befolkning om, at Beijing begynder at levere på løfter fx om 'genforening af moderlandet'.

Fastholdelse af stabilitet, økonomisk vækst og fremgang for alle kinesere er som nævnt den anden vigtige søjle i partiets indenrigspolitiske legi- 
timitetsgrundlag. Det kræver stabile relationer til vigtige handelspartnere og sikring af adgang til markeder, energi og naturressourcer. Drevet af disse hensyn er Kina nu til stede og aktiv økonomisk, politisk og militært - primært bidragende til FN's fredsbevarende operationer - i en grad ikke set tidligere i områder og lande langt væk fra Kinas traditionelle interessesfære som fx i Afrika og Mellemøsten.

\section{Silkevejen}

'Den Nye Silkevej' står som det stærkeste udtryk for den mere selvhævdende kinesiske udenrigs- og sikkerhedspolitik, men også her spiller indenrigspolitiske drivkræfter en væsentlig rolle. Som led i den igangværende omstilling af den kinesiske økonomiske model søger Beijing at anvende 'Den Nye Silkevej' til at omstrukturere og opgradere den kinesiske industri ved at opkøbe eller investere $\mathrm{i}$ internationale virksomheder, som er førende inden for innovation og avancerede teknologier.

Det fremgår af Kinas 'Made in China 2025'-strategi, som understreger, at Kina senest i 2025 skal have en innovationsbaseret økonomi førende inden for forskning og udvikling. Indbygget heri er ambitionen om at anvende 'Den Nye Silkevej' til at udbrede og internationalisere kinesiske standarder, designs og løsninger. Det er særligt oplagt inden for højhastig- hedstog og telekommunikation, hvor Kina efterhånden er ved at have etableret verdensførende brands og virksomheder.

Der arbejdes benhårdt på dette fra kinesisk side, og her er det bemærkelsesværdigt, hvordan Trump-administrationen ved vedtagelsen af handelssanktionerne vendt mod Kina i foråret 2018 specifikt fremhævede dem som et modsvar på Kinas 'Made in China 2025'-strategi. Det tyder på, at denne bliver taget meget alvorlig i Washington, og at den strategiske rivalisering mellem USA og Kina i stigende grad også viser sig ved en tiltagende konkurrence om udvikling og kontrol af ny viden og avancerede teknologier.

I Kina kobles dette op med et fokus på såkaldte nye frontiers, som er en kinesisk betegnelse for særlige områder - specifikt fremhæves de polare områder, det dybe hav, rummet og cyberspace - hvor fremtidens stormagter, set fra Beijing, især vil komme til at konkurrere om bedst at kunne begå sig og udnytte de nye ressourcer, der bliver tilgængelige. Målsætningen er, at Kina tager føringen.

\section{Behov for nytænkning}

$\mathrm{Xi}$ Jinping har angivet retningen, og der lægges ikke længere skjul på ambitionerne. Kina vil være en førende stormagt og vil have den indflydelse og respekt, som svarer hertil. 
Beijing er klar over, at grundlaget lægges indenrigspolitisk. Her er budskabet også klart - de strukturelle omlægninger af økonomien og åbningen over for omverdenen vil blive fortsat, men det vil ske på en mere styret og kontrolleret vis. Set fra Beijing kan den mere markedsstyrede, dynamiske og innovative kinesiske økonomi, som der arbejdes hen imod, kun realiseres med et stærkere, mere centraliseret, effektivt og 'rent' (mindre korrupt) kommunistparti i spidsen.

Der er stor beslutsomhed, og der arbejdes fokuseret. De visioner og ambitioner, som ligger bag igangværende udviklinger i kinesisk indenrigspolitik og udenrigs- og sikkerhedspolitikken, er tæt sammenvævede. Det er som sådan ikke nyt, men det er karakteren og omfanget af de visioner og ambitioner, som Xi Jinping har præsenteret.

Udviklingen de senere år af Kina som en selvsikker og ambitiøs stor- magt vil fortsætte. Hvordan USA, men også Europa, håndterer et sådant Kina, spiller afgørende ind. Der er meget på spil. Både i Beijing og Washington er der en intensiveret debat i gang om, hvordan udviklingen $\mathrm{i}$ modpartens udenrigs- og sikkerhedspolitik skal forstås og håndteres.

Det er umuligt at sige, hvordan det vil ende. To ting er imidlertid sikkert - Kinas interesse- og indflydelsessfære vil fortsætte med at brede sig, og USA kan ikke diktere eller sanktionere sig frem til at få Kina til at gøre, som USA gerne vil have. Der kræves nytænkning og tilpasninger i begge lejre - som fornemt formuleret af den amerikanske sinolog David Lampton: "America has to rethink its objective of primacy and China must recalibrate its own sense of strength and what that entitles it to". 